\title{
Analysis of Cameroon's forestry sector: implication for sustainable management
}

\author{
M. B. BAMBOT ${ }^{*}$, N. M. TCHAMBA and N. E. NTABE \\ Department of Forestry, Faculty of Agronomy and Agricultural Sciences (FASA), \\ University of Dschang, Cameroon. \\ Corresponding author, E-mail: mbabiilo@yahoo.co.uk; Tel : +237 75727139
}

\begin{abstract}
Cameroon forestry sector has undergone profound institutional and legislative reforms for the past decades. Consequently, the objective of this paper is to examine the activities of Cameroon administration focused on the strategies for sustainable management of the forestry sector. The target population for achieving this objective constituted members of the forest administrative personnel. Primary data resulted from structured questionnaire and interview of key persons, secondary data resulted from consultation of annual reports and adequate literatures. Result revealed a drastic drop in labour force in all the categories; technical incompetence of more than $81 \%$ of the personnel notably with respect to the accomplishment of certain tasks; majority of the respondents agreed with the following: decision making process did not give room for everybody's opinion; decisions taken, did not reach every level; no quality interaction between superior staff and subordinates and hardworking staffs were rarely usually rewarded. Nevertheless, most of the respondents revealed that the impact of decentralization in the forestry sector and the contribution to the national economy are positive. Consequently, decision makers of the forestry sector should consider the development of human capacity as a priority in view of personnel motivation of the sector, to better accomplish assigned tasks.
\end{abstract}

(c) 2011 International Formulae Group. All rights reserved.

Keywords: Forest administration, motivation, devolution of responsibilities, bureaucracy.

\section{INTRODUCTION}

It is incontrovertible that for any sustainable development to be achieved by any nation, the human resource management and technical know-how must play a significant and critical role. The forestry sector is expected to provide human capacity with leadership role that will meet the challenges of stimulating sustainable development and democratization of knowledge.

In Cameroon, the dependence of the majority of the population on agricultural and renewable natural resources (RNR) for liveli- hood and sustenance is substantial especially in the rural areas where large proportion of the population of this country resides. Coincidentally, most of the region's poor people live in these rural areas and their number is roughly twice that of the urban poor.

This prevalent situation in Cameroon thus, gives credence to the assertion that neither lack nor availability of RNR determines the poverty status of Cameroon but lack of appropriate and adequate human resources to develop and make use of a scientific technology in adding value to these RNR and also to 
attract investments. This scenario thus, constitutes part of the imperatives for sustained human resource management in agriculture, forestry, and other RNR management in Cameroon, if the objectives of Millennium Development Goals (MDGs), especially tackling poverty and hunger, are to be achieved in Cameroon.

Among Cameroon's numerous natural resources, the most important is the forest, the most directly threatened. It covers more than $60 \%$ of the national territory. Cameroon's forests are among the most species rich in the Congo basin and ranks among the top six countries in Africa in terms of total numbers of mammals, birds and higher plants. Much of this diversity is found within lowland forests and in the Atlantic coastal forests where high numbers of primate species including lowland gorillas, chimpanzees, drills and Columbus monkeys are found. With 22 million hectares of forests, Cameroon has the second largest forest reserves in Africa after Democratic Republic of Congo. The dense forests, the dry and humid savannah areas are made up of various ecological sub-types reflecting the geographical diversity of Cameroon. Cameroon is endowed with a unique forest heritage in Africa and the world and ranks among the top six countries in Africa in terms of total numbers of mammals, birds and higher plants (Talbott, 1993; FAO 1995) and is one of the richest and most varied wildlife resources in the African continent. These include: 409 mammal species; 183 reptile species; 849 bird species; 190 amphibian species; 39 butterfly species (Cameroon Forestry Policy, 1995).

Throughout the past decades, the management of this heritage has been given priority over the Concerns of the government (MINEF, 1998). The forestry law, updated periodically, has laid down the guidelines and procedures for a conservatory management of resources (D'Silva and Appanah, 1995; Egbe, 2001). The management of Cameroon's forests has been evolving with the developmental challenges of Cameroon as a nation. Its administration has therefore evolved with political and economic developments.
Despite all efforts, it has been noticed that the forest is decreasing at an alarming rate due to a combination of avoidable and unavoidable factors, thereby posing a serious threat to the survival of the people (FAO, 1992, 1993; Nguifo, 1999).

The contribution of the forestry sector to government's effort towards development and rational distribution of natural resources has of late fallen short of desired level. This has been one of the major observations made by authorities of the Ministry of Forestry and Wildlife who had since March of 2003 been meeting with stakeholders to identify what can be done to reverse the situation. The relatively poor contribution of the forestry sector is the consequence of insufficient human, material and financial resources attributed to forestry control activities and the follow up of forestry crime. The main objective of this study was therefore to review the forestry management in Cameroon with a view to determining its strength within the framework of sustainability.

\section{MATERIALS AND METHODS \\ Study area}

Cameroon is a country of $455,000 \mathrm{~km}^{2}$ and borders the Republic of Chad, the Central African Republic, Nigeria, Equatorial Guinea, Gabon, Congo and the Atlantic Ocean. It has forests, Sudano-Guinea Savannah, as well as Sahelian savannah ecosystems. The forest constitutes one of Cameroon's major resources covering more than $40 \%$ of the national territory.

\section{Climate}

Cameroon has two seasons; the dry season and the rainy season. Most of the rainfall in the south of the country is between March and October. The humid southeast trade influences rainfall over the Atlantic Ocean and the south-west monsoon winds over the Gulf of Guinea. Rainfall diminishes as one moves from the coast to the hinterland. Maximum rainfall is recorded in Debundscha with a mean of $1000 \mathrm{~mm}$ per year. 


\section{Vegetation}

The vegetations of Cameroon provide a complete spectrum of that of inter tropical Africa with dense humid forest in the south (Lectouzey, 1980). The coast is made up of mangrove forest while the very swampy areas, creeks and estuaries are covered by raffia palms. The most common species within the mangrove forest are Rhizophora racemosa (Red mangrove) and Avicennia (Black mangrove). The equatorial rain forest lies inland after the mangrove forest and is located mostly between altitude 200 and $800 \mathrm{~m}$.

\section{Sources of data and instrument for data collection}

The population for this study was made up of the administrative staff members in forestry administration of some regions in Cameroon. Therefore, an opportunistic sampling technique was used to obtain data on the staff.
Table 1 indicates the distribution of staff members concerned with administration in the various regions concerned. Primary data were collected by means of structured questionnaire, while secondary data were obtained from the desk review of annual reports and literatures of the Ministry of Forestry and Wildlife; Ministry of Finance, National Agency for the Development of Forests (NADEF, ONADEF) and offices of regional delegations of Forestry (Figure 1). In-depth interview with key informants was made on background characteristics of the respondents effectiveness of delegation of duty in Forestry Administration; determination the strength of forestry administration from 1992 - 2004; nature of work environment of the forestry set up; extent of proficiency and the quality and quantity of the work force of forestry activities; and problems militating against the forestry set up in Cameroon.

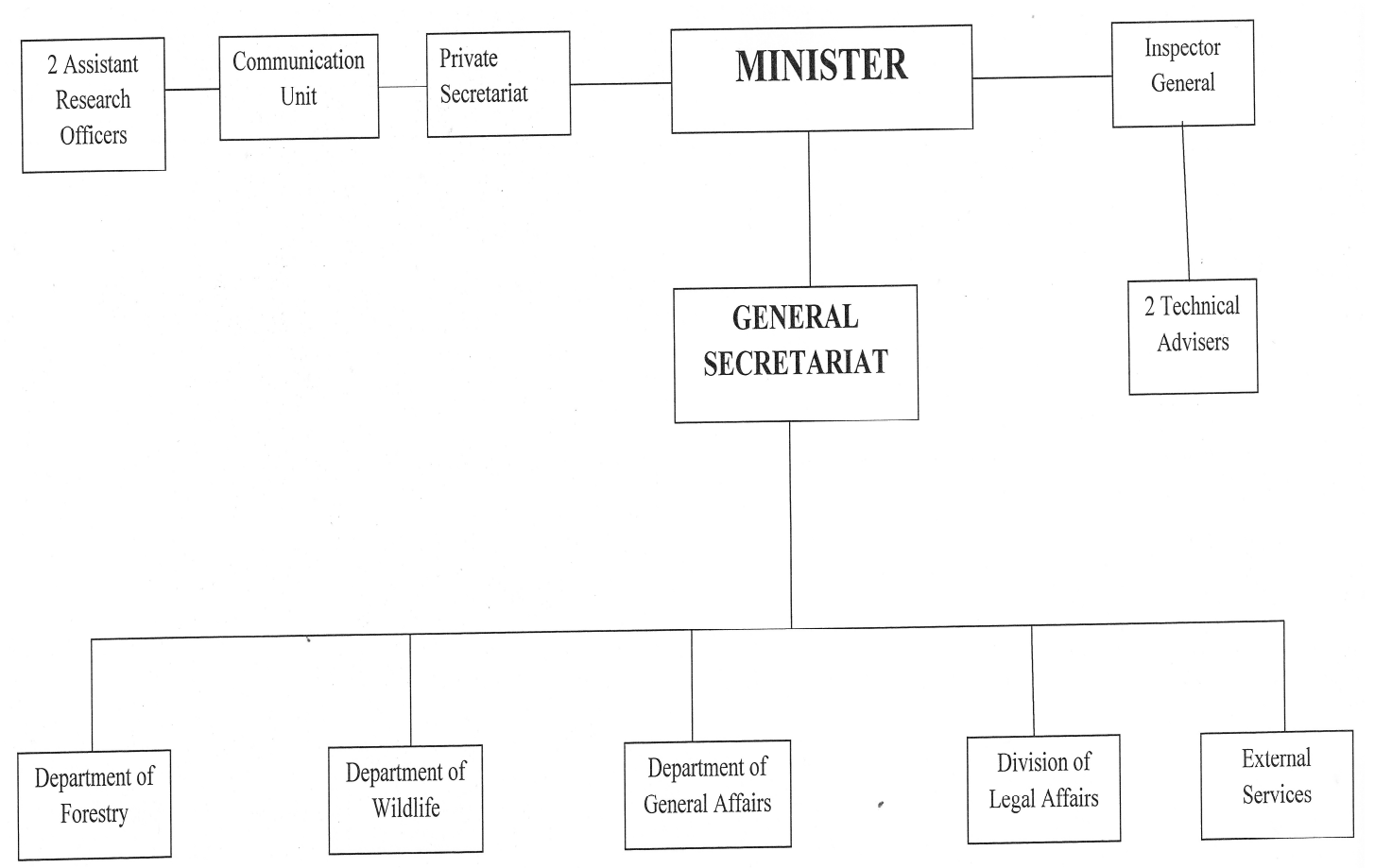

Figure 1: The Minister's Cabinet. Source: MINFOF, Yaoundé, 2005. 
Table 1: Visited areas and corresponding sampled population size.

\begin{tabular}{llc}
\hline S/N & Regions & Staff members of MINFOF \\
\hline 1 & North West & 22 \\
2 & South West & 15 \\
3 & West & 18 \\
4 & Littoral & 14 \\
5 & Centre & 16 \\
6 & South & 13 \\
7 & East & 11 \\
Total & & 109 \\
\hline
\end{tabular}

RESULTS

Demographic profile of the forestry staff in Cameroon

The gender distribution of the forestry staff indicates that the forestry sector in Cameroon is male dominated $(85.7 \%)$ with 95.2\% married, and prevalent family size among the staff members ranged between 7 8 people in a household. $42.9 \%$ of the staff was within the age group of $43-47$ Years. On the educational status, $66 \%$ of the workforce was holders of professional technical certificate in forestry while about 28.6 percent are B.Sc. graduates (IEFC) (Table 2).

Quality and quantity of forestry workforce concerned in administrative duties in Cameroon

As shown in Table 3, the number of forestry workforce in all the categories in Cameroon declined drastically over the years under study. Table 4 reveals that $52.4 \%$ of the workforce had low level of proficiency. A relatively small population (2\%) is highly competent to discharge their duties. $81 \%$ percent of the staff members admitted that the technically competent on the job was not adequate. About $61.9 \%$ had not participated in any workshop and seminar presentation since joining the forestry service while $71.4 \%$ had not attended training after their recruitment. Also, $81.0 \%$ of the staff admitted that logistics are inadequate for the execution of their duties. This therefore implies that reengineering of both administrative and funding support is unavoidably expedient to enable the forestry sector perform at maximum potential.

Distribution of respondents based on the nature of job environment

As indicated in Table 5, 76.2\% of the respondents disagreed that decision making process give room for everybody's opinion; $76.2 \%$ disagreed that when decisions are taken, they reach every level; $90.5 \%$ agreed that slow information flow affect their job; while $85.7 \%$ disagreed that there is quality interaction between superior and low officers. On the other hand, $71.4 \%$ of the respondents disagreed that hardworking staffs are usually rewarded.

\section{Perceived impact of devolution of forestry administration on the development of forestry sector \\ On the perceived impact of devolution} of forestry administration (Table 6), all the respondents $(100 \%)$ indicated the creation of the Ministry of Forestry and Wildlife will enhance Forestry Sector while $61.9 \%$ indicated that enactment of the 1994 law has made the forestry sector contribute to the economic development than before. On the effectiveness of delegation of duties to lower level staff, all the respondents $(100 \%)$ confirmed that this will highly enhance the smooth functioning of management of forestry sector; while on the involvement of rural communities, $76.2 \%$ indicated that delegation of responsibility to local community has greatly improved the management of forest resources. 
Table 2: Demographic profile of the forestry staff in study areas.

\begin{tabular}{llccc}
\hline Items & Variables & Frequency & Percentage & Mode \\
\hline $\mathbf{1}$ & Gender & & & \\
& Female & 28 & 25.7 & Male \\
& Male & 81 & 74.3 & \\
& Sub-total & 109 & 100.0 & \\
\hline $\mathbf{2}$ & Age & & & \\
& $32-37$ & 20 & 18.4 & \\
& $38-42$ & 19 & 17.4 & $43-47$ years \\
& $43-47$ & 40 & 36.7 & \\
& $48-55$ & 30 & 27.5 & \\
& Sub-total & 109 & 100.0 & \\
\hline $\mathbf{3}$ & Marital status & & & \\
& Single & 27 & 24.8 & \\
& Married & 82 & 75.2 & Married \\
& Sub-total & 109 & 100.0 & \\
\hline $\mathbf{4}$ & Household size & & & \\
& 4-6 & 70 & 7.0 & $4-6$ individu- \\
& 7-8 & 30 & 27.5 & als \\
& 9-10 & 9 & 8.3 & \\
& Sub-total & & 100.0 & \\
\hline $\mathbf{5}$ & Educational status & & & \\
& Technical & 74 & 67.9 & Technical \\
& B.Sc. & 24 & 22.0 & \\
& M.Sc. & 11 & 10.1 & \\
& Sub-total & 109 & 100.0 & \\
\hline
\end{tabular}

Table 3: Nature of job environment in Cameroon forestry machinery.

\begin{tabular}{llll}
\hline S/N & Items & Yes & No \\
\hline 1 & Decision-making process gives room for everybody's opinion & 19 & 90 \\
2 & When decisions are taken, they reach every level fast & 19 & 90 \\
3 & Does slow information flow affect your job effectiveness & 100 & 9 \\
4 & There is quality interaction between superior and low officers & 60 & 49 \\
5 & Hard working staffs are usually rewarded & 43 & 67 \\
\hline
\end{tabular}

Table 4: Perceived impact of decentralization of the forestry administration on the development of forestry sector in Cameroon.

\begin{tabular}{llll}
\hline $\mathbf{S} / \mathbf{N}$ & Items & Yes & No \\
\hline $\mathbf{1}$ & $\begin{array}{l}\text { The creation of the MINFOF will enhance the development of } \\
\text { the forestry sector }\end{array}$ & $100 \%$ & $0 \%$ \\
\hline $\mathbf{2}$ & $\begin{array}{l}\text { The enactment of the 1994 forestry law has made the forestry } \\
\text { sector contribute to economic development more than before }\end{array}$ & $95 \%$ & $5 \%$ \\
\hline $\mathbf{3}$ & $\begin{array}{l}\text { The delegation of responsibilities to officers of the lower level } \\
\text { will highly enhance the smooth functioning of sustainable } \\
\text { management of the forestry sector }\end{array}$ & $100 \%$ & $0 \%$ \\
\hline $\mathbf{4}$ & $\begin{array}{l}\text { The delegation of responsibilities to local communities has } \\
\text { greatly improved their standard of living and the sustainable } \\
\text { management of the forest resources. }\end{array}$ & $100 \%$ & $0 \%$ \\
\hline
\end{tabular}


Table 5: Distribution of respondents based on the nature of job environment.

\begin{tabular}{llll}
\hline S/N & Items & Yes & No \\
\hline 1 & Decision making process give room for everybody's opinion & $23.8(5)$ & $76.2(16)$ \\
2 & When decisions are taken, they reach every level fast & $23.8(5)$ & $76.2(16)$ \\
3 & Does slow information flow affect your job & $90.5(19)$ & $9.5(2)$ \\
4 & There is quality interaction between superior and low officers & $14.3(3)$ & $85.7(18)$ \\
5 & Hard working staffs are usually rewarded & $71.4(15)$ & $28.6(6)$ \\
\hline
\end{tabular}

Table 6: Perceived impact of devolution of forestry administration on the development of forestry sector.

\begin{tabular}{llll}
\hline $\mathbf{S} / \mathbf{N}$ & Items & Yes & No \\
\hline 1 & $\begin{array}{l}\text { The creation of Ministry of Forestry, Wildlife and Protected Areas will } \\
\text { enhance the development of the Forestry Sector }\end{array}$ & $100(21)$ & $0(0)$ \\
\hline 2 & $\begin{array}{l}\text { The enactment of the 1994 law has made the forestry sector contribute } \\
\text { to economic development than before }\end{array}$ & $61.9(13)$ & $38.1(8)$ \\
\hline 3 & $\begin{array}{l}\text { The delegation of responsibility to officials of the lower level will highly } \\
\text { enhance the smooth functioning of management of forestry sector }\end{array}$ & $100(21)$ & $0(0)$ \\
\hline 4 & $\begin{array}{l}\text { The delegation of responsibility to local community has greatly improved } \\
\text { the management of forest resources }\end{array}$ & $76.2(16)$ & $23.8(5)$ \\
\hline
\end{tabular}

\section{DISCUSSION}

The gender distribution could be due to the active nature of the job, also it could be attributed to enrolment pattern at the schools awarding technical and higher degree certificate in forestry science. In Cameroon, the forestry sector is regarded as paramilitary corps. The dominant age group of the forestry staff portrays that they were relatively young and are quite energetic to execute the functions as expected of them. Within the socio-cultural context of the study area, married people are usually accorded respect for being responsible and emotionally stable. With many of the forestry staff married, this indicates that the staff would definitely consider their job very important since it would provide a means of sustainable livelihood for their households. Considering their appointments, these might definitely lead to higher levels of job commitments which will be very desirable towards the attainment of the set goals of the Ministry of Forestry and Wildlife.

Forestry technicians form the majority of staff. One may assume the human capacity building of the sector is at its peak in terms of forestry technicians. However there is need for special human capacity building among the staff member to update the knowledge of the level on modern techniques. There could be assurance of professional efficiency among the top ranking officers while such might not be obtained among the technicians. High level of academic training in related fields should be given to those technical qualifications. It is expected that a good deal of achievement could still be made if rigorous human capacity building could be considered as a priority. The number of forestry workforce in all the categories in the region is declining drastically over the years. It was also observed that some of the workers who were dead or retired or being transferred were not replaced. This has been as a result of government's recent economic policy of no recruitment of civil servants in the public service machinery. The result of the workforce reported low level of proficiency with relatively small population being highly competent to discharge their duties. This implies that the forestry services performance or delivery is likely to be poorly executed. This further suggest that priority attention is required if the ministry's set goals are to be achieved. Generally, there seems to be a consensus that the forestry staffs are limitedly or not at all exposed to on-the-job human capacity building, through quality-time training and refresher courses. This could have served as motivation and as a means to aid creativity.

The result of the distribution of respondents based on the nature of their job environment indicates that effective implementation of work especially in the grass root level 
cannot be effective because of the bureaucracy or red-tape nature in administration in the forestry sector.

This is due to the one sided manner of administration i.e. from top to bottom. Most of the respondents disagreed that decision making process gives room for everybody's opinion; when decisions are taken, they reach every level; slow information flow affect their job; there is quality interaction between superior and low officers; and that hardworking staffs are not usually rewarded. On the perceived impacts of devolution of forestry administration on the development of forestry sector in Cameroon, all the interviewed forestry staff rated the impact made by the ministry of forestry high. This implies that the establishment of the Ministry of Forestry in 1992 and the involvement of local communities in the management of forest resources had met the expected goal. Recent creation of the Ministry of Forestry and Wildlife was welcomed and timely, because this has called for more specialization and greatly contributed to economic development than before. However, based on the present scenario, the extent of achievement by the Ministry in future date would not be the same as when it started. Decision-making process is highly centralized and relatively little real authority is delegated to the lower level; this has slowed down the smooth functioning of the forestry machinery.

Contrary to the above, the majority of the forestry staff rated the current state of forestry administration in Cameroon as very low. This percentage level in Cameroon is disturbing as the degree of ineffectiveness might increase in future (Inyang, 2004, 2005). Indepth interview with key informants further revealed that sustainable funding and human capacity building are relatively unstable in the forestry administrative set up and these could explain the reason why many of the staff rated the administrative performance as ineffective

Although some 1,438 posts out of a total 1,978 established posts for MINFOF are located in 'Services Exterieurs', less than 300 are located in the field. The remainders are based at regional and divisional offices and have little or no contact with forest activities. Shortage of field staff, coupled with an inadequate budget allocation for both capital and recurrent expenditure at field level, severely constrains the effectiveness of 'Services Ex- terieurs'. The problem is so acute that field staff, which each cover areas of several thousand square kilometres is not able to travel into the forest unless transport is provided by the logging companies whose operations they are meant to be regulating.

The situation outlined above results in:

(i) weak linkages between policy formulation and implementation;

(ii) the absence of clear lines of authority and accountability; and,

(iii) inappropriate allocation of resource between operational and administrative/support activities.

This situation has arisen as a result of Cameroon's regional administrative arrangement which vest significant power in the ten regional governors. It is unlikely that this arrangement can be altered significantly and therefore any move to improve co-ordination and management of local resources may need to be relying largely on the development of operating procedures and activities rather than changes in lines of reporting or responsibility.

MINFOF limited access to government resources in comparison to ONADEF has limited its ability to recruit and retain suitably qualified and experienced staff. This coupled with a general restriction on recruitment, has contributed to be skill shortage.

\section{Forest concession}

With the assistance of the international community, the Cameroon government has set up a number of projects to test its strategies for the sustainable and environmentally friendly management of the forests. Inventories carried out by state bodies on 14 million hectares of humid forest shows a timber potential of about 1.527 thousand million $\mathrm{M}^{3}$ containing over 600 exploitable species. To date, only 300 species are marketable of which only about 60 are exploited on regular basis. This volume should be quadrupled if paper pulp and fuel wood are taken into consideration (MINFOF, 2008).

On the basis of the present timber market conditions, the exploitable potentials stands at about $750 \mathrm{~m}^{3}$ made up of three categories namely:

A: Rich species $=120$ million $\mathrm{m}^{3}$

B: Intermediate species $=280$ million $\mathrm{m}^{3}$

$\mathrm{C}$ : Currently marketed species $=350$ million $\mathrm{m}^{3}$ 
This reform is legal instrument delegating responsibilities to local communities (Vabi et al., 2000). But sadly enough, the emergence of senior political and military figures in the forestry sector from the late 1990s onwards mirrors the environmentallyand socially-devastating political economy of logging in Cameroon. The involvement of such figures does not benefit the development of domestic forest management capacity; instead it seems to be introducing a new scale of political involvement in the forestry sector that can only hinder the application of natural forest law and slow the progress of introducing transparency and accountability.

It is commonly accepted that a few large, mostly European companies dominate the logging industry. Two third of the concession areas are partially or wholly controlled by non-Cameroonian companies, although the affiliation of about $15 \%$ of concession owners recorded is unknown.

The legal status of concessions appears to be questionable. Article 7 of the 'document des normes' calls for a buffer zone that is 'a protected area around the boundaries of each National Park, Natural reserves, or Wildlife reserve', Cameroon Environmental Watch, C. E.W. (1999) The selective nature of logging companies, resulting in only harvesting the best quality trees of a limited number of species implies a low extraction rate per unit area. This practice causes over exploitation of specific species and has been characterized as timber mining.

Proper regeneration of logged areas is often prevented by logging companies returning for second cuts too soon and increase agricultural and hunting pressures associated with logging road access. Logging development threatens the integrity of Cameroon's protected areas in a variety of ways. Active concessions fall within the boundaries of several forest reserves. For instance although no legal concessions are found within $\mathrm{Dja}$, Cameroon's largest protected forest, this reserve is now encircled by active licences apparently in violation of the existing legislation. This development will hamper effort to protect adjacent forestlands. Logging roads associated with concessions may facilitate access by poachers and other encroachers on the reserves.
In the absence of a final management plan, forest exploitation around reserves continues unfettered on the lands that by law belong to a buffer zone. This development hampers opportunities to protect surrounding forest that would help ensure the integrity of (one of) Cameroon's most important conservation areas (Nguifo, 1999).

\section{Forest protection and management in Cameroon}

Through reafforestation programs (to sequester carbon) and careful management and protection of remaining primary forests (to retain carbon), Cameroon could continue to provide a global environmental service. According to Hummel (1984), forestry performs three functions: protection, production, and recreational. Although there will be conflicts between the three functions, especially the first two, consistency within proper forestry administration and the execution of forest policy is essential.

\section{Conclusion}

More than one third of the population admitted that the nature of work environment require serious re-engineering and over hauling of the Forestry Sector in Cameroon. The policy makers in the sector should therefore give some priority to human capacity development of the staff in other to motivate them for greater and improved job delivery. It is expedient that without material and financial resources needed to execute duties, much would not be achieved. Therefore there should be improvement in the amount of material and financial support to the forestry sector in Cameroon.

Irrespective of the proliferation of forestry graduates from forestry institutions in the country, the main objective of producing qualitative manpower that can provide the leadership to meet the challenges, stimulate sustainable development and provide solutions to the country's problems is still yet to be realized, if compared to the past when the few trained Cameroon forestry graduates ranked among the best in the Central African sub region. Various reasons had been attributed to this, among which are poor funding, loss of incentives, bureaucratic bottlenecks, brain drain, outdated research, teaching and learning curricula and facilities among others. 
The essence of highlighting the structural and managerial perspective and some of the challenges that inhibit sustainable growth and development of forestry sector is to retrospect the motive for establishing and updating the human resource capability in the forestry machinery. It is important to reiterate the fact that these challenges are still to device ways of going about them, an issue which is more important in this kind of discourse.

The crux of the strategies to be adopted at surmounting these challenges appears to be the area of provision of adequate funding and facility for all aspect of capacity building, research and education in agriculture and RNR. Irrespective of this, it is important that Cameroonian researchers and educators also have a paradigm shift in their research and educational activities in terms of continuous self development and imbibing of international best practices.

\section{REFERENCES}

Bigombe P. 1998. Towards decentralization of forest management in Cameroon: The dynamics of the contest between the forester state and the construction of participatory management of forest resources. Forest Trees and People. Newsletter No. $15 \& 16$, pp. 2-12.

Cameroon Forestry Policy. 1995. General Policy Document, June 1995 pp 4 -16.

Cameroon Environmental Watch (C.E.W.) 1999. Rapport intermediaries 1 project conjoint Cameroon Environment Watch, CARPE et ECOFAC Cameroon, février 1999.

D’Silva E, Appanah S. 1995. Forestry Management for sustainable Development. An EDI Seminar Report Number 32. The World Bank. pp. 46.

Egbe S. 2001. The Law, Communities and Wildlife Management in Cameroon; Rural Development Network, ODI. pp. 1-10.

FAO. 1992. The State of Forestry in the Region Secretarial Note, African Forestry and Wildlife Commission, Ninth Session, Kigali, Rwanda. 10 - 14 August, 1992. FAO:AFWC/92/3.FAO. pp.14

FAO. 1993. The Challenge of Sustainable Forest Management. What Future for the World's Forest? FAO, p.128.
FAO. 1995. Forest resources assessment 1990 survey of tropical forest cover and study of Change processes FAO forest paper 130. FAO, ROME, ITALY, p.28.

Hummel T. 1984. The effectiveness of national forestry administration in Africa. International Review of Administrative Sciences, 58(2): 163 - 174.

Lectouzey. 1980. Vegetable of Cameroon. Atlas of the United Republic of Cameroon. pp. 20-24. Legal Regulations on Forestry and Wildlife. (13 March 1986): A Compendium of official in struments on forest and wildlife management in Cameroon. pp. 9-14.

Mengang MJ. 2004. Evolution of Natural Resource Policy in Cameroon. Yale F. and ES bulletin, p.3.

MINEF. 1998. Manual of the Procedures for the Attribution and Norms for the Management of Community Forests. Ministry of Environment and Forests, Government of Cameroon, p. 88.

Nguifo S. 1999. Exploitation forestiére, une menace croissante. Moabi Newsletter No. 078, Juin 1999.

Nguiffo S. 2004. Remarks on the NeoPatrimonial Administration of Cameroon's Forestry Sector. p.12.

Nyuylime LP. 2004. Forestry Control, Independent Observer Solicited. Cameroon Tribune, Yaoundé. p. 9.

Sandrine L. 2004. European Union involvement in Africa's rainforests, Cameroon. p. 41.

Simon HA. 1968. Administrative Behaviors. A Study of Decision-Making Processes in Administrative Organization. The Free Press: New York, USA; 259.

Talbott K. 1993. Central Africa's Forest. The Second Greatest Forest System on Earth. World Resource Institute: Washington, D.C.; 27.

Vabi MB, Ngwasiri CN, Galega PT, Oyono PR. 2000. Devolution of Responsibilities linked with forest management to local communities: Context and obstacles to realization in Cameroon. WWF-CPO Publication, p 40.

WWF. 1993. Project Planning in Forest Management. Report on Community Forest Project in Cameroon. WWF, p. 42. 